\title{
E.P. THOMPSON: HISTORIAN AND SOCIALIST
}

\author{
by ELLEN MEIKSINS WOOD
}

In the early 1960s, when E.P. Thompson published his classic, The Making of the English Working Class, history writing was still a favorite vehicle for left intellectuals. There was no great mystery about the contribution of this ground-breaking work of historical scholarship to the politics of the socialist project. When Thompson crafted his marvelous and much quoted phrase about rescuing ordinary people from "the enormous condescension of posterity"-a phrase quoted in just about every obituary-it did not sound like romantic nostalgia or like some kind of populist antiquarianism (which is the tone all too often given to it by people who quote it now). Instead, it held a clear and immediate political message about the agency of the working class in making its own history, a message that goes to the heart of the socialist project as the self-emancipation of the working class.

Today things are different. They are different not only for the obvious reason that the very idea of socialism, not to mention the concepts of class and class struggle, is being challenged even by substantial sections of the left, but also because the left is losing sight of the historian's craft as a political project. So an appreciation of Thompson's work now has to do something more than remind us of the tremendous influence he has had on working-class history and on social

This is a modified version, with a new concluding section, of a talk given at a memorial seminar on E. P. Thompson at York University, Toronto, the proceedings of which are being published in Studies in Political Economy. Ellen Meiksins Wood teaches political science at York University. 
history in general, or of his role in creating what is often called the "new left." We cannot even take for granted that people on the left, and especially intellectuals, will recognize the political resonance of history.

When I talk about the politics of history, what I have in mind is not the subordination of historical scholarship to ideological preconceptions, or anything like that. On the contrary. I am talking about history as critique, as a way of exposing ideological presuppositions, a means of achieving critical distance from what is commonly taken for granted. This kind of critical "discourse" is not much in fashion today. But I think it is more now than just a matter of history (and maybe even political economy) being displaced by, say, cultural studies as the privileged discourse of left intellectuals. I guess we all know that this is part of a larger picture-what for lack of a better word people have been calling postmodernism, with its rejection of grand narratives, totalizing knowledge, even conceptions of causality, and so on. But this too is part of an even larger picture-a picture that I would characterize as a general submission to what is. And what is, of course, is capitalism. Capitalism is triumphant and universal. The market is an inevitable natural law. History is over.

The critique of capitalism is out of fashion-and here there is a curious convergence, a kind of unholy alliance, between capitalist triumphalism and socialist pessimism. The triumph of the right is mirrored on the left by a sharp contraction of socialist aspirations. Left intellectuals, if they are not actually embracing capitalism as the best of all possible worlds, have little hope for anything more than a bit more space within the interstices of capitalism; and they look forward, at best, to only the most local and particular resistances. And there is another curious effect of all this. Capitalism is becoming so universal, so much taken for granted, that it is becoming invisible.

Now clearly we have plenty to be pessimistic about. Recent and current events have given us plenty of cause. But there is something curious about the way many of us are 
reacting. If capitalism has indeed triumphed, you might think that what we need now more than ever is a critique of capitalism. Why is this the right moment to embrace modes of thought which seem to deny the very possibility not only of surpassing capitalism but even of critically understanding it? How are we supposed to gain access to a critical knowledge of capitalism if we start with modes of thought which see only contingency, fragmentation, difference, and are generally hostile to any notion of capitalism as a systemic unity, any notion of a systemic logic, or even any notion of causality?

I really do think we are in an unprecedented situation now, something we have not seen in the whole history of capitalism. What we are experiencing is not just a deficit of action, or the absence of the necessary instrumentalities and organization of struggle (though those are certainly thin on the ground). It is not only that we do not know how to act against capitalism but that we are forgetting even how to think against it.

This is why I think that Thompson's historical project is more important now than it has ever been. This may be the most important political legacy of his historical work-that more than any other historian, or maybe even any other scholar or writer of any kind, he brought to life the specificity, historicity, and contestability of capitalism as an economic, social, and moral system. I cannot think of anyone more skillful at achieving the kind of anthropological distance a critique of capitalism requires, anyone better at bringing the otherness of capitalism into sharp relief, or anyone better at displaying it to us as a contested terrain.

Thompson never takes capitalism for granted. He never just submits to its presuppositions, as even many other Marxists have done. In his work, the capitalist mode of production, its forces and relations of production, stand out in all their distinctiveness and difference, and they appear as real historical products, real social practices, always in process, always contested. 
So, for example, a lot of his work is devoted to challenging market rationality, to demonstrating its specificity and historicity-and not just as an abstraction but as a set of social practices and moral principles. The most obvious instance is his classic essay on the "Moral Economy of the Crowd," where he asks us to observe the contestation of market rationality, in the process of being resisted by opposing customs and expectations, different conceptions of the right to subsistence. Or consider his work on changing definitions of property and the contestation of capitalist definitions. The most recent example is the essay in Customs in Common on "Custom, Law, and Common Right." Here you see new capitalist definitions of property asserting themselves against, and being resisted by, different conceptions of use-rights, as capitalist conceptions of productivity, particularly in the notion of "improvement," begin to establish themselves, even in law, as a title to property.

Or take his attack on the concept of "industrialization," the tendency to treat industrialization as a single, neutral, ahistorical, technologically-determined process, and his insistence on the specificity of industrial capitalism, as a development determined not just by some neutral process of technological progress but by the specific logic of capitalism and its specific mode of exploitation, its specific drive for productivity and labor-discipline. His essay on "Time, WorkDiscipline and Industrial Capitalism" is one of the best examples of the kind of thing I have in mind. It does a brilliant job of conveying the specificity of capitalism, not only the great transformation in work practices and social relations it entailed but also the tremendous existential changes it involved, in something as fundamental as our experience of time.

I use Thompson's essays a lot in teaching an undergraduate course on the rise of capitalism, where my main objective is to detach students from their most unquestioned assumptions about the universality and trans-historical quality of the society in which they live, its conceptions of human nature, rationality, and social values. I use these essays, in spite of their difficulty, because I simply have not found any better expres- 
sion of critical liberation than Edward Thompson's history. But no one should think for a minute that it is only unsophisticated undergraduates who need this kind of lesson. There are even Marxists who could do with some of his cautionary lessons about capitalist development as a neutral, ahistorical technological process.

And that, of course, is nothing compared to the dominant, mainstream conceptions of historical process and the development of the modern world. You only need to read some of the standard historical literature to see how thoroughly enclosed the most sophisticated scholars are in the assumptions of the capitalist order, so that the contestation of capitalist principles is literally unthinkable for them. They think about capitalism and its historical development in capitalist categories, assuming the very things that need to be explained.

The point that needs to be emphasized, though, is that Thompson is not just engaging in a nihilistic deconstruction of capitalist categories. He is treating them as historically determinate phenomena with a systemic origin in specific social property relations, responding to some identifiable causalities, which, by the same token, are contestable by human agencies. The opponents of capitalism have certainly lost many contests in history, but they can also win.

Thompson's main political legacy as a historian, then, is teaching us to think in non-capitalist ways and to envisage the possibility of contestation. He acknowledges that "We shall not ever return to precapitalist human nature," but, he continues, "a reminder of its alternative needs, expectations, and codes may renew our sense of our nature's range of possibilities." And restoring our sense of the range of possibilities is at least a start in challenging the universal triumph of capitalism.

Where, then, does his work as a political campaigner in the peace movement fit in? Rereading his lecture "Beyond the Cold War" (prepared as the Dimbleby lecture for the BBC, which inexplicably canceled it), I was struck by something. He 
talks about the Cold War as a detour, a disruption in the common history of Europe:

Let us go back, first, not to the origin of the Cold War, but to a moment just before it broke out. My own generation is the last which witnessed that moment as adults. Our perception of "Europe" remains, to this day, a little different from that of younger generations. Europe, for us, included Warsaw, Prague, and Budapest and, more distantly, Leningrad and Moscow....

The young have grown up within a fractured continent. The Cold War has been a received condition, which has set the first premises of politics and ideology from before the time of their birth....

But it has not always been there. I do not suggest that Europe, before the Cold War, was in any way, politically or culturally, united. . . Yet the savage divisions among Europeans did not exist as a fracture splitting the continent in half. They ran deeply within the political and cultural life of each nation-state. ${ }^{2}$

The common European history Thompson and his generation on the left foresaw was the advance of democratic socialism. That common history was derailed by the Cold War and by its threat to the very survival of humanity. So the peace movement, while it was in Thompson's view a very necessary detour, even a matter of survival, was a detour nonetheless. And Thompson evidently hoped that European history would resume its course, which apparently meant turning its attention away from divisions between geopolitical fragments of Europe back to the divisions within each European society, the terrain of real emancipatory struggles and especially class struggles.

If Thompson believed that the derailment of history by the Cold War obliged him to turn his attention away from those struggles, I see no reason to doubt that he still had great hopes for their eventual resumption. I see no reason to doubt that, throughout his years in the peace movement, he still had hopes for the project of democratic socialism, or that class divisions and class struggles, generously and pluralistically defined, were still going to be at the center of this project as Thompson understood it. The way the Cold War actually 
ended, and the way "Europe" is actually becoming reunited, must have been a blow to his hopes for the resumption of those suspended struggles. But as the contradictions of capitalism become more and more evident in all parts of Europe and everywhere else, those hopes are likely to prove justified again; and people will learn again not only to think but to act, live, and struggle against capitalism.

NOTES

1. E. P. Thompson, Customs in Common (New York: New Press, 1992), p. 15.

2. E. P. Thompson, Beyond the Cold War (New York: Pantheon, 1982), p.3.

When questions of "class interests" are eliminated from public controversy a victory is thereby gained for the possessing, conservative class, whose only hope of security lies in such elimination. Like a fraudulent trustee, the bourgeois dreads nothing so much as an impartial and rigid inquiry into the validity of his title deeds. Hence the bourgeois press and politicians incessantly strive to inflame the working class mind to fever heat upon questions outside the range of their own class interests.-James Connolly. 